\title{
REVISION OF THE GENUS TIBRACA STÂL (HETEROPTERA, PENTATOMIDAE, PENTATOMINAE)
}

\author{
José Antônio Marin Fernandes ${ }^{1,2}$ \\ Jocélia Grazia ${ }^{1,3}$
}

\begin{abstract}
The genus Tibraca Stål, 1860 is revised, and some taxonomic changes are introduced. The following species are considered to belong in this genus: Tibraca limbativentris Stål, 1860, T. similima Barber, 1941, and T. exigua sp.n. (from Argentina). Three other species, formerly placed in Tibraca, are considered respectively: $T$. obscurata Bergroth, 1914, incertae sedis; Mecocephala fusca (Haglund, 1868), comb.n.; Ogmocoris hypomelas (Burmeister, 1835). The genus Ogmocoris Mayr, 1864 is reinstated.

KEY WORDS. Heteroptera, Pentatomidae, Tibraca, Ogmocoris gen. reval., taxonomy
\end{abstract}

STÅL (1860) described Tibraca to include T. limbativentris; he compared it with Mecocephala Dallas, 1852, and emphasized that Tibraca could be distinguished by the absence of abdominal sulcus. 1835.

MAYR (1864) established Ogmocoris for Atelocerus hypomelas Burmeister, in Brazil.

HAGLUND (1868) described $T$. fusca based on a male supposedly collected

WALKER (1868) described Mormidea basalis; this name however fell in homonymy with Mormidea basalis Walker, 1867.

LETHIERRY \& SEVERIN (1893) gave the new name Mormidea walkeri for the preoccupied name M. basalis Walker, 1868.

KIRKALDY (1909) considered Mormidea walkeri as junior synonym of $T$. limbativentris.

BERGRoth (1914) described T. obscurata based on a female from French Guyana.

BARBER (1941) described T. similima from Ecuador.

SiLVA (1945) considered Ogmocoris reinigeri Costa Lima, 1935 as a junior synonym of $T$. limbativentris.

Costa Lima (1947) established the genus Ogmocoris Mayr, 1864 as a junior synonym of Tibraca.

The type specimens of all species so far known in Tibraca were examined, except for T. obscurata. As mentioned in CAMPOS \& GRAZIA (1995), the type specimen of $T$. obscurata is probably lost. Furthermore, Bergroth's description of this species does not permit to place it correctly. Then T. obscurata is considered here as "incertae sedis".

1) Departamento de Zoologia, Universidade Federal do Rio Grande do Sul. Avenida Paulo Gama, 90046-900 Porto Alegre, Rio Grande do Sul, Brasil.

2) Bolsista de Doutorado, FAPESP. E-mail: josefern@vortex.ufrgs.br

3) Bolsista do CNPq. E-mail: jocelia@vortex.ufrgs.br 
The study of the male genitalia, allied to other morphological characters, permitted to the authors to transfer T. fusca to the genus Mecocephala, and reestablish the genus $O g$ gmocoris as valid. The genus Ogmocoris will be treated in a future paper. described.

Tibraca exigua sp.n. from Southern Brazil, Argentina and Uruguay, is herein

Tibraca limbativentris and $T$. similima are redescribed, emphasizing the diagnostic characters, especially those of the genitalia of both sexes.

The specimens studied belong to the following collections: Rijksmuseum van Natuurlijke Historie, Leiden, Netherlands (RMNH); Coleção Entomológica, Departamento de Zoologia, Universidade Federal do Rio Grande do Sul, Porto Alegre, Rio Grande do Sul, Brazil (UFRG); Museu de Zoologia, Universidade de São Paulo, São Paulo, São Paulo, Brazil (MZSP), Coleção de Entomologia Pe. J. S. Moure, Departamento de Zoologia, Universidade Federal do Paraná, Curitiba, Paraná, Brazil (DZUP); American Museum of Natural History, New York, New York, USA (AMNH); Museu de Ciências Naturais, Fundação Zoobotânica do Rio Grande do Sul, Porto Alegre, Rio Grande do Sul, Brazil (MCNZ); Coleção Entomológica, Faculdade de Agronomia, Universidade Federal de Pelotas, Pelotas, Rio Grande do Sul, Brazil (UFPL); División de Entomologia, Museo de La Plata, Universidad Nacional de La Plata, La Plata, Argentina (MLPA); Entomological Collection, Department of Entomology, National Museum of Natural History, Washington, District of Columbia, USA (USNM); Naturhistoriska Riksmuseet, Stockholm, Sweden (NHRS); Museo de Entomologia, Departamento de Arthropodos, Faculdad de Ciencias, Universidad de la Republica, Montevideo, Uruguay (UYIC).

Measurements are given in millimeters. For the new species $T$. exigua four males and three females were measured.

\section{Tibraca Stål, 1860}

Tibraca Stål, 1860: 18. - Stål, 1867: 26. - Stål, 1872: 30. - Lethierry \& Severin, 1893: 132. - Kirkaldy, 1909: 72. - Costa Lima, 1947: 312.

Ogmocoris; Costa Lima, 1947: 313 (syn.) (error).

Type species: Tibraca limbativentris Stål, 1860 (by monotypy)

Castaneous to dark castaneous. Head long and acuminate. Anterolateral margins of pronotum yellowish. Body length arising 10.00 to 16.00 long. Abdominal width arising 6.00 to 8.00 long.

Head longer than the width between eyes and nearly as long as pronotum; anteocular portion longer than wide. Jugae and tylus subequal in length. Jugae progressively narrowing to apex. Antennae: segment I not attaining apex of head; segment III the longest; I longer than II; V longer than IV; segment IV slightly dorsoventrally depressed and longitudinally sulcated. Head in profile with jugae in a lower level than tylus. Bucculae rectilinear, in profile, weakly developed and evanescent at base of head. Rostrum attaining at least the first urosternite. Rostrum: segment I as long as bucculae but not hidden by them; segment II shorter than III and IV together. Dorsal punctures of head regularly distributed, ventral punctures concentrated close to antenniferous tubercles and base of bucculae. 
Pronotum trapezoidal, anterior angles distinctly toothed. Anterolateral margins rectilinear, entire and yellowish. Humeral angles not developed. Pronotum densely and uniformly punctured.

Thorax ventrally and irregularly punctured. Prosternum and mesosternum piceous. Anterior half of mesosternum carinate. A narrow row of white hairs along mesosternum. Metasternum shallowly concave. Each ostiolar ruga clavated. Evaporatory area matte. Tibiae dorsally sulcated. Femora and tibiae with piceous dots. Coxa, trocanters and tarsi immaculate. Basal angle of scutelum foveate, apex rounded not attaining posterior border of fifth segment. Posterior angle of corium acute reaching sixth segment of connexivum. Apex of radial vein with a small pale yellow callus. Hemelytral membrane hyaline and infuscate, veins brown sometimes bifurcate. Well-exposed connexivum with concolorous punctures. Connexivum with margins subcalosed and fuscous; postero-lateral angles weakly projected.

Ventral surface with smaller and more concentrated punctures than in the dorsal surface. Sutures of abdominal segments fuscous near lateral margins. Each trichobothrium separated by a longitudinal imaginary line tangential to the spiracles.

Male. Pygophore quadrangular, globose opening dorso-posteriorly. Dorsal rim excavated in an open "U". Postero-lateral angles rounded, slightly projected. Ventral rim forming two layers; the superior one expanded in $1+1$ breast-like structures, postero-ventrally directed and $1+1$ cylindrical arms dorsally-directed, each one beside segment $\mathrm{X}$. Inferior layer carinated with $1+1$ conical projections, that are close together; bristles sparsely distributed between superior and inferior layers. Segment X (proctiger) cylindrical, apex rounded with $1+1$ basal processes. Parameres reduced and trapezoidal in profile. Phallus dorso-ventrally depressed. Dorsal connectives short; processus capitati well developed. Phallotheca with $1+1$ median, ventral, digitiform processes (processus phallothecae) almost parallel and shorter than processus conjunctivae 1. Postero-lateral angles of phallotheca developed. Conjunctiva with two processes. Processus conjunctivae 1 in $1+1$ divergent, slightly sclerotized arms beside processus phallothecae 1; processus conjunctivae 2 in $1+1$ lateral digitiform structures. Vesica in a membranous collar ventrally excavated in an open "U" and dorsally with a shield-like processus (processus vesicae). Opening of vesica ventrally-directed, ductus seminis distalis extremely long helicoidal and very delicate, normally not preserved after dissection.

Female. Posterior border of gonocoxites 8 arched, mesial borders parallel. Posterior border of laterotergites 8 forming an obtuse angle, spiracles absent. Apices of laterotergites 9 rounded and surpassing transverse band linking laterotergites 8 dorsally. Gonocoxites 9 trapezoidal, antero-lateral angles expanded into narrow and curved arms. Gonapophyses 9 with a pair of secondary thickening. Thickening of vaginal intima conical. Ductus receptaculi before and after vesicular area very long, but not as long as in Hypatropis Bergroth (FERNANDES \& GRAZIA 1996); ductus helicoidal after vesicular area, and occasionally wound before vesicular area. Pars intermedialis with a basal sclerotized ring. Annular crests well developed and parallel. Capsula seminalis globose.

Comments. Tibraca belongs to a monophyletic group formed by Mecocephala Dallas, 1851, Paratibraca Campos \& Grazia, 1995, Glyphepomis Berg, 1891, Parahypatropis Grazia \& Fernandes, 1996 and Hypatropis Bergroth, 1891; the 
states of characters found in male genitalia, shared by these genera, represent the synapomorphies of the genera. BENVEGNÚ (1968) studied the pygophore and phallus of T. limbativentris, M. acuminata Dallas, 1851 and Paramecocephala foveata Benvegnú, 1968 and recognized the similarities among them. In Tibraca and Mecocephala, besides the biggest size of the body, the head is longer than wide, acuminate at apex, with a lighter band on pronotum and ostiolar ruga extending through $1 / 3$ of evaporatory area width.

The shorter rostrum and the absence of median abdominal sulcus separate Tibraca from Mecocephala.

Distribution. Tibraca is found in Caribbean, Northwest Neotropical and Souheast Neotropical regions (AMORIM \& PIRES 1996). Its species have been reported from rice crops. T. limbativentris has the widest known distribution of all species ranging in Neotropical region from Southeast area to Northwest and Caribbean areas; $T$. similima is restricted to Ecuador, and $T$. exigua, found in South Brazil, Argentina and Uruguay.

\section{Key for identification of the species of Tibraca}

1. Abdominal area between trichobothrial and lateral margins yellowish, sparsely punctured. Basal processes of proctiger, in males, in a posteriorly directed horn-like projection $\ldots \ldots \ldots \ldots \ldots \ldots \ldots \ldots \ldots \ldots \ldots \ldots \ldots \ldots \ldots \ldots \ldots \ldots$

- Abdominal area between trichobothrial and lateral margins yellowish, with punctures almost as concentrated as in the abdomen. Basal processes of proctiger, in males, in a conical projection .......... similima Barber

2. Small specimens (equal or shorter than $12.0 \mathrm{~mm}$ ); legs red to dark red. Processus conjuntivae 1, in males, digitiform and dorsally curved at apex . .exigua sp.n.

- Large specimens (equal or longer than $13.0 \mathrm{~mm}$ ); legs castaneous, concolor with the body. Processus conjuntivae 1 , in males, widened at apex, in profile . . . limbativentris Stål

\section{Tibraca limbativentris Stål, 1860}

Figs $1,2,7,8,11,16,17,22,23,28$

Tibraca limbativentris Stål, 1860: 19. - Stål, 1872: 30. - Berg, 1879: 48. - Lethierry \& Severin, 1893:

132. - Kirkaldy, 1909: 72. - Bosq, 1937: 127. - Barber, 1941: 111. - Costa Lima, 1947: 312. -

Pirán, 1956: 32. - Ruffinelli \& Pirán, 1959: 21. - Benvegnú, 1968: 88. - Becker \& Grazia, 1971: 20.

Mormidea basalis Walker, 1868: 553 (praeoc.).

Mormidea walkeri Lethierry \& Severin, 1893: 124 (nom.n.). - Kirkaldy, 1909: 72 (syn.).

Tibraca basalis; Distant, 1899: 438.

Ogmocoris reinigeri Costa Lima, 1935: 16. - Silva, 1945: 596 (syn.). - Costa Lima, 1947: 311.

Holotype female labeled "Brasilia [Rio de Janeiro]; 65 82; Typus; Naturhistoriska Riksmuseet Stockholm Loan n ${ }^{\circ} 747 / 91 "$ " (NHRM), examined.

One hundred and twenty three specimens were examined from: DOMINICAN REPUBLIC: Juma-Ponao; GuADALUPE: Estación de Rujol (on rice); Costa RicA: Heredia: Sarapiqui (on rice); Colombia: Valle del Cauca, Palmira (on rice); 

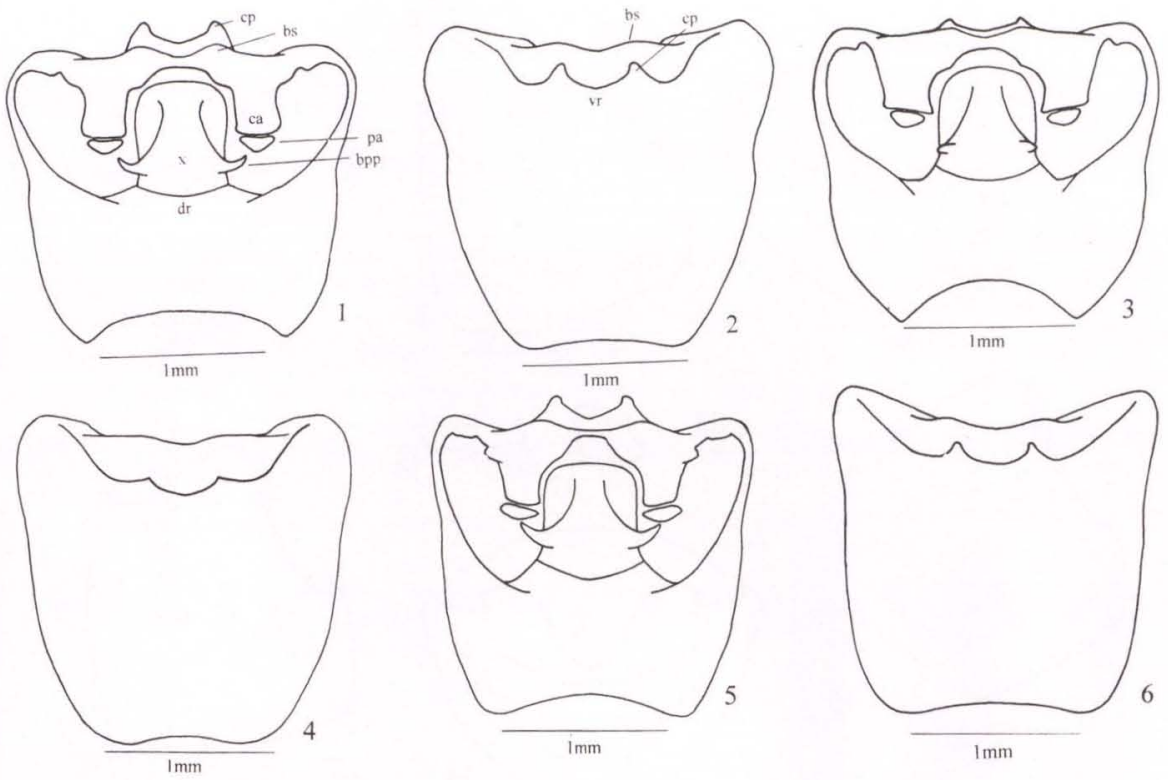

Figs 1-6. Pygophores: $(1,2)$ Tibraca limbativentris dorsal and ventral view, respectively; $(3,4)$ Tibraca similima dorsal and ventral view respectively; $(5,6)$ Tibraca exigua dorsal and ventral view respectively. (bs) Breast-like structures of superior layer of ventral rim, (bpp) basal process of proctiger, (ca) cylindrical arms of superior layer of ventral rim, (cp) conical projections of inferior layer of ventral rim, (dr) dorsal rim, (pa) paramere, (vr) ventral rim, $(x)$ tenth abdominal segment.

Venezuela: Guarico, Calabozo, Portuguesa: La Aparición, Payara; BRAzIL: Amazonas, Pará, Maranhão, Tocantins, Goiás, Bahia, Minas Gerais, Mato Grosso, Espirito Santo, Rio de Janeiro, Santa Catarina, Rio Grande do Sul; PERU: Lamarca: Bagua, Loreto: Yurimaguas; Bolivia: La Paz, Sapecho, Alto Beni (on rice). According to Costa Lima (1947) e TrujILlo (1991) T. limbativentris occurs on rice in Argentina.

Body length from 13.0-16.0. Pronotal width 6.7-8.0. Abdominal width 6.6-8.0. Male. Pronotal lateral margin impunctured or rarely punctured in the posterior half. Ostiolar ruga two or three times larger than openning of scent gland, developed through $1 / 3$ to $1 / 4$ metapleural width. Legs concolorous with the body. Abdominal area between trichobothria and lateral margin yellow sparsely punctured, punctures shallower than the abdominal ones. Basal processes of proctiger in a posteriorly directed hornlike projection(Fig. 21). Processus conjunctivae 1 a little widened at apex, in profile (Fig. 23).

Female. Similar to male. Ductus receptaculi, before vesicular area, almost three times longer than this area; ductus equal in diameter, before and after vesicular area (Fig. 28).

Comments: The holotype female of Mormidea basalis Walker, 1868 (= Mormidea walkeri) was also examined. 

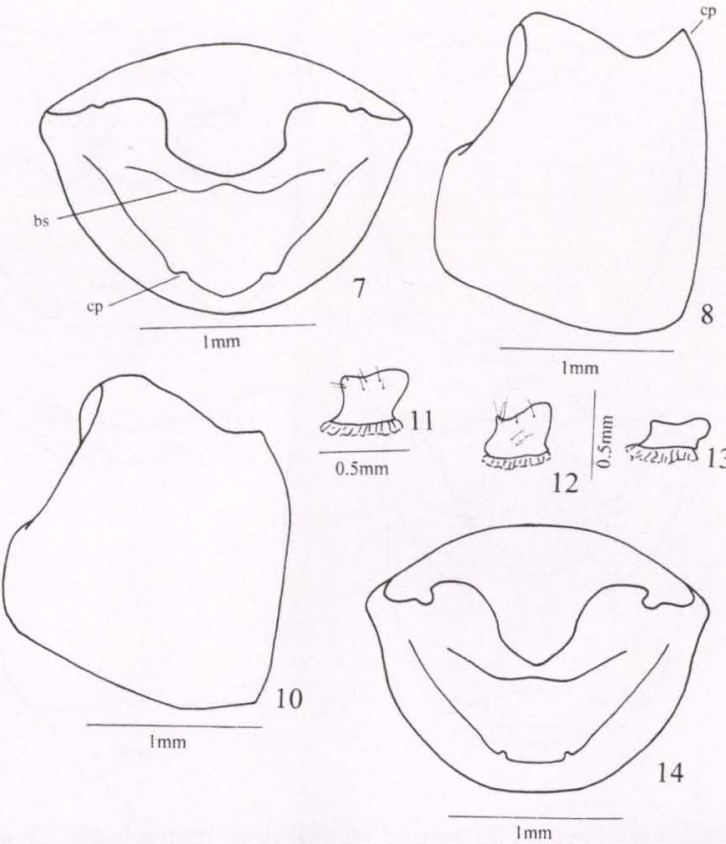
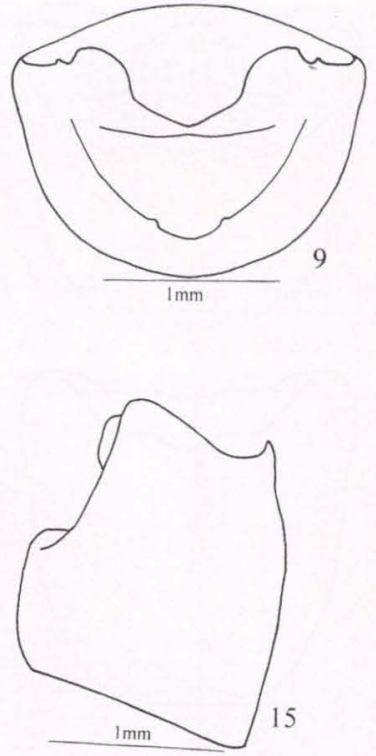

Figs 7-15. (7-10, 14-15) Pygophores: $(7,8)$-Tibraca limbativentris posterior and lateral view respectively; $(9,10)$ Tibraca similima posterior and lateral view respectively; $(14,15)$ Tibraca exigua posterior and lateral view respectively. (11-13) Parameres: (11) T. limbativentris; (12) T. exigua; (13) T. similima. (bs) Breast-like structures of superior layer of ventral rim, (cp) conical projections of inferior layer of ventral rim.

\section{Tibraca similima Barber, 1941}

Figs $3,4,9,10,13,18,19,24,25,30$

Tibraca similima Barber, 1941: 110; Costa Lima, 1947: 313.

Holotype male labeled "Santa Ana, Ecuador, VI-1939, F. Campos; Pest in Rice field; male; Tibraca similima Barb., Type det. H.G. Barber; Type $\mathrm{n}^{\circ} 55160$ USNM" (USNM), examined.

Thirty one specimens were examined from: ECUADOR: Azuay: Cuenca, Manabi: Portoviejo, Santa Ana, Guayas: Guayaquil.

Body length from 13.0-15.0. Pronotal width 6.7-8.0. Abdominal width 6.6-8.0. Male. Pronotal lateral margin punctured; punctures not uniform in size. Ostiolar ruga two or three times larger than openning of scent gland, developed through $1 / 3$ to $1 / 4$ metapleural width. Legs concolorous with the body. Abdominal area between trichobothria and lateral margin yellowish with punctures almost as concentrated as in the abdomen. Basal processes of proctiger in a conical projection (Fig. 3). Processus conjunctivae 1 widened at apex, in profile (Fig. 25).

Female. Similar to male. Ductus receptaculi, before vesicular area around five times longer than this area; diameter of the ductus, before vesicular area, larger than the diameter after vesicular area (Fig. 30). 

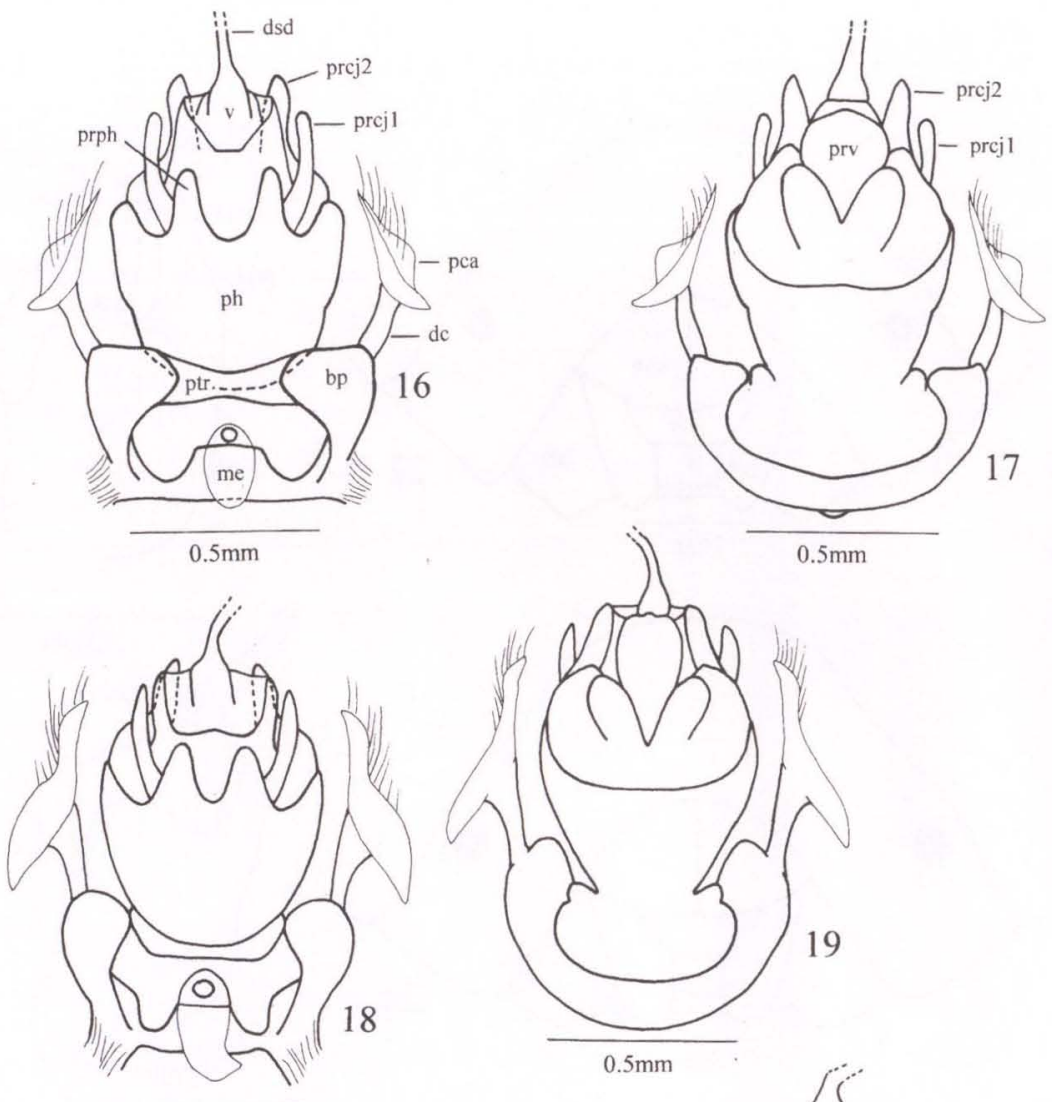

$0.5 \mathrm{~mm}$
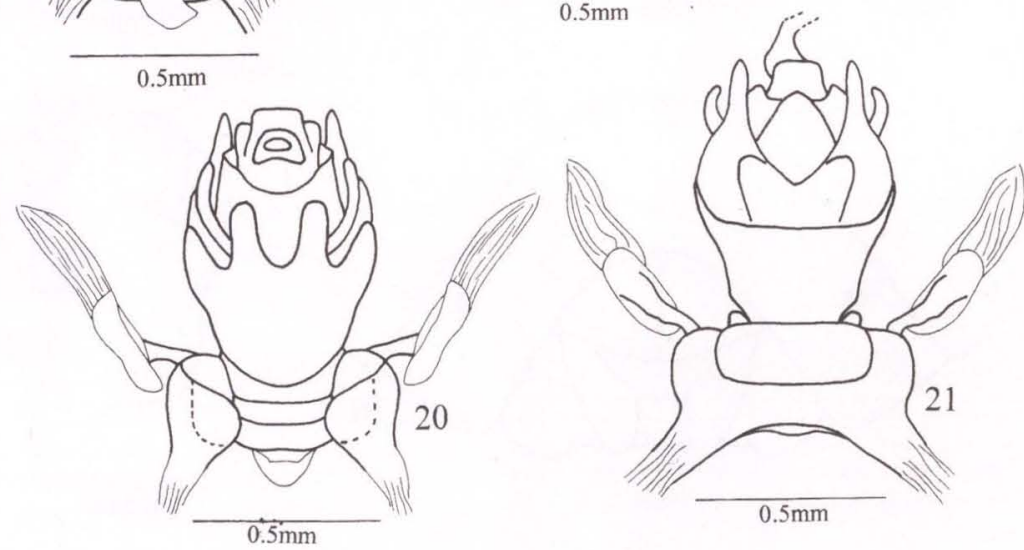

Figs 16-21. Phallus: (16-17) Tibraca limbativentris ventral and dorsal view respectively; (18-19) Tibraca similima ventral and dorsal view respectively; (20-21) Tibraca exigua ventral and dorsal view respectively. (bp) Basal plates of articulatory apparatus, (dc) dorsal conectives, (dsd) ductus seminis distalis, (me) membranblase, (pca) processus capitati, (ph) phallotheca, (prcj1) processus conjunctivae 1 , (prcj2) processus conjuntivae 2, (prph) processus phallothecae, (prv) processus vesicae, (ptr) ponticulus transversalis, (v) vesica. 

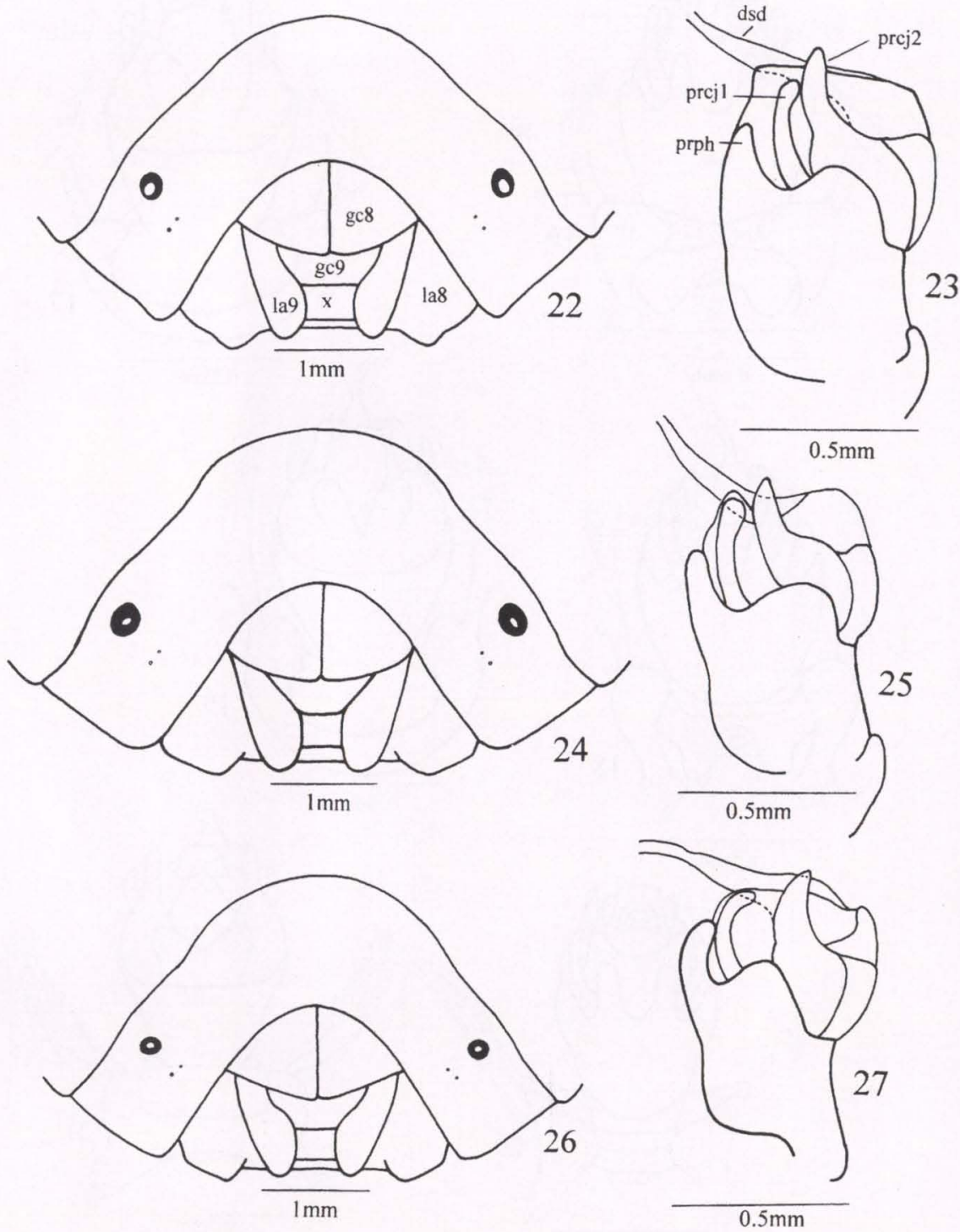

Figs 22-27. (23, 25, 27) Phallus lateral view: (23) Tibraca limbativentris; (25) Tibraca similima; (27) Tibraca exigua. $(22,24,26)$ Female genital plates, ventral view: (22) Tibraca limbativentris; (24) Tibraca similima; (26) Tibraca exigua. (dsd) Ductus seminis distalis, (gc8) gonocoxites of eight segment, (gc9) gonocoxites of ninth segment, (la8) laterotergites of eight segment, (la9) laterotergites of ninth segment, (prcj1) processus conjunctivae 1, (prcj2) processus conjuntivae 2 , (prph) processus phallothecae, $(\mathrm{x})$ tenth abdominal segment. 


\title{
Tibraca exigua sp.n.
}

\author{
Figs $5,6,12,14,15,20,21,26,27,29$
}

Male. Very similar to T. limbativentris but smaller in size. Body length from 9.0-12.0. Length of head 2.1-2.4; anteocular length 1.2-1.4; width of head 1.9-2.2; width between eyes 1.1-1.4; anteocular width 0.9-1.0. Pronotal length 2.0-2.7; pronotal width 5.2-6.0. Scutellar length 3.3-4.4; basal width 3.2-3.9. Abdominal width $0.54-0.65$. Pronotal lateral margins impunctated or rarely punctated at posterior half. Ostiolar ruga shorter than in the previous species, as long as or slightly larger than opening of scent gland, developed 1/6 through metapleural width. Legs red to dark red. Abdominal area between trichobothria and lateral margin yellowish with sparse and castaneous punctures, occasionally absent. Basal processes of proctiger in a posteriorly directed horn-like projection (Fig. 5). Processus conjunctivae 1 digitiform and dorsally curved at apex, in profile (Fig. 27). Other characters as described for genus.

Female. Similar to male. Ductus receptaculi, before vesicular area, conspicuously longer than in the previous species, exceeding ten times the length of this area; ductus equal in diameter before and after vesicular area (Fig. 29).

Type material. Holotype male: ARgEnTINA, Entre Rios: Pronuntiamente, I-1965, F.H. Walz, Museum Leiden. (RMNH). Paratypes: BRAzIL, Santa Catarina: Joinvile, Coleção Diringshofen, 1 female (UFRG); 1 female, \# 060; 1 female, \# 061. (MZSP). Corupá, Hansa Humboldt, A. Maller, Frank Johnson Donor Collection, 1 female, XI-1919, Tibraca simulans H. Ruckes (not described), Tibraca ruckesi McDonald (not described); 1 male, XII-1944, Tibraca simulans H. Ruckes (not described), Tibraca ruckesi McDonald (not described); 1 female, X-1948, Tibraca simulans $\mathrm{H}$. Ruckes (not described), Tibraca ruckesi McDonald (not described) (AMNH). Rio Grande do Sul: Pelotas, 1 male, V-1990, Schoens; 1 male, 10-VI1990, M. N. Miranda; 1 male, VI-1990, Costa; 1 female, VI-1990, Marques; 1 female, 28-IV-1991, von Laer; 1 female, V-1991, Zepka (UFRG); 1 male, IV-1991, Monteiro; 1 female, VI-1991, Marcolin; 1 male, 24-IV-1993, Maguelly (MCNZ); 1 male, 17-V-1991, Chapon (UFPL); 1 female, III-1991, Oliveira; 1 male, 25-III1991, Dal Molin (MLPA); 1 male, III-1991, Silveira (AMNH); 1 male, 27-V-1994, Zanusso (MZSP); 1 male, 20-II-1991, Wetzel; Canguçu, 1 male, 8-V-19919, Moreira (DZUP); Capão do Leão, 1 male, 03-I-1991, Beskow (USNM). ARGENTINA, Cordoba: Almafuerte, La Cascada, 1 female, XII-1964, F.H. Walz; El Quebracho, 1 female, I-1965, F. H. Walz (RMNH). Buenos Aires: Buenos Aires, Berisso, 04-XI-1973, O. S. Flint (USNM). Uruguay, 1 male and 1 female, Boucard, Naturhistoriska Riksmuseet Stockholm Loan \# 744/91 and \# 745/91, respectively (NHRS); Montevideo, Sayago, 1 female, 1942, Tibraca limbativentris Pirán det.; Santiago Vázquez, 1 male, 5-XI-1961, C.S. Morey, Tibraca limbativentris Pirán det.; 1 male, 21-IX-1960, en caraguatá; 1 male, 15-X-1960, entre yuyos (UYIC).

\section{Incertae sedis}

\section{Tibraca obscurata Bergroth, 1914}

Tibraca obscurata Bergroth, 1914: 431. - Barber, 1941: 111. - Costa Lima, 1947: 313. - Campos \& Grazia, 1995: 170-171. 


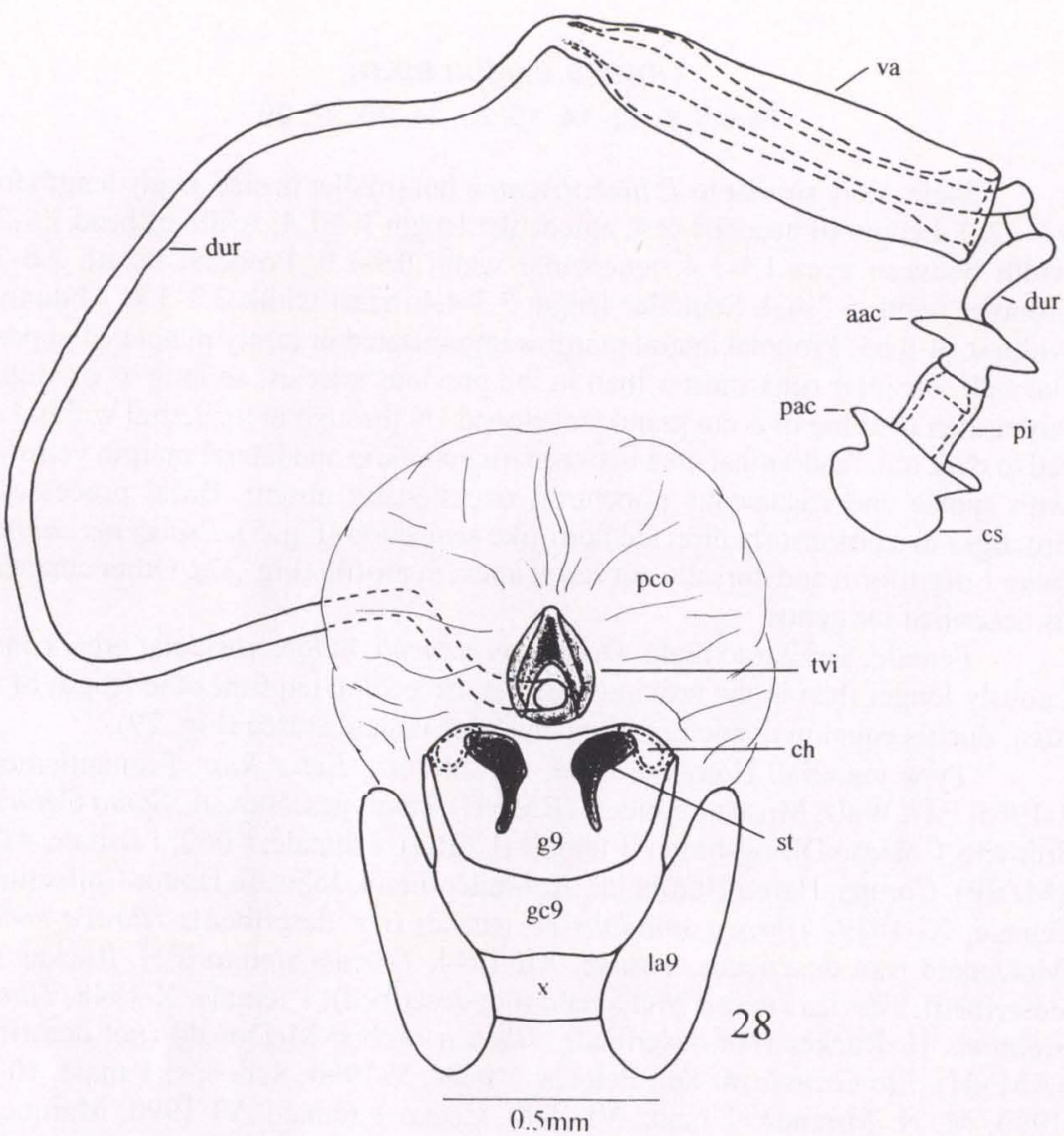

Figs 28. Tibraca limbativentris. Laterotergites, gonocoxites and gonapophyses of ninth segmment, and ectodermical genital ducts, ventral view. (aac) Anterior annular crest, (ch) chitinellipsen, (cs) capsula seminalis, (dur) ductus receptaculi, (g9) gonapophyses of ninth segment, (gc9) gonocoxites of ninth segment, (la9) laterotergites of ninth segment, (pac) posterior annular crest, (pco) pars communis, (pi) pars intermedialis, (st) secondary thickenings of gonapophyses 9 , (tvi) thickening of vaginal intima, (va) vesicular area, (x) tenth abdominal segment.

\section{Transfered species}

\section{Mecocephala fusca (Haglund, 1868), comb.n.}

Tibraca fusca Haglund, 1868: 151; Stål, 1872: 30. - Lethierry \& Severin, 1893: 132. - Kirkaldy, 1909:

72. - Barber, 1941: 110. - Costa Lima, 1947: 313.

\section{Reinstated genus}

\section{Ogmocoris Mayr, 1864, gen. reval.}

Ogmocoris Mayr, 1864: 908 (Type species: Atelocerus hypomelas Burmeister, 1835, by monotypy).Lethierry \& Severin, 1893: 132. - Stål, 1872: 30.

Tibraca; Costa Lima, 1947: 313 (error). 


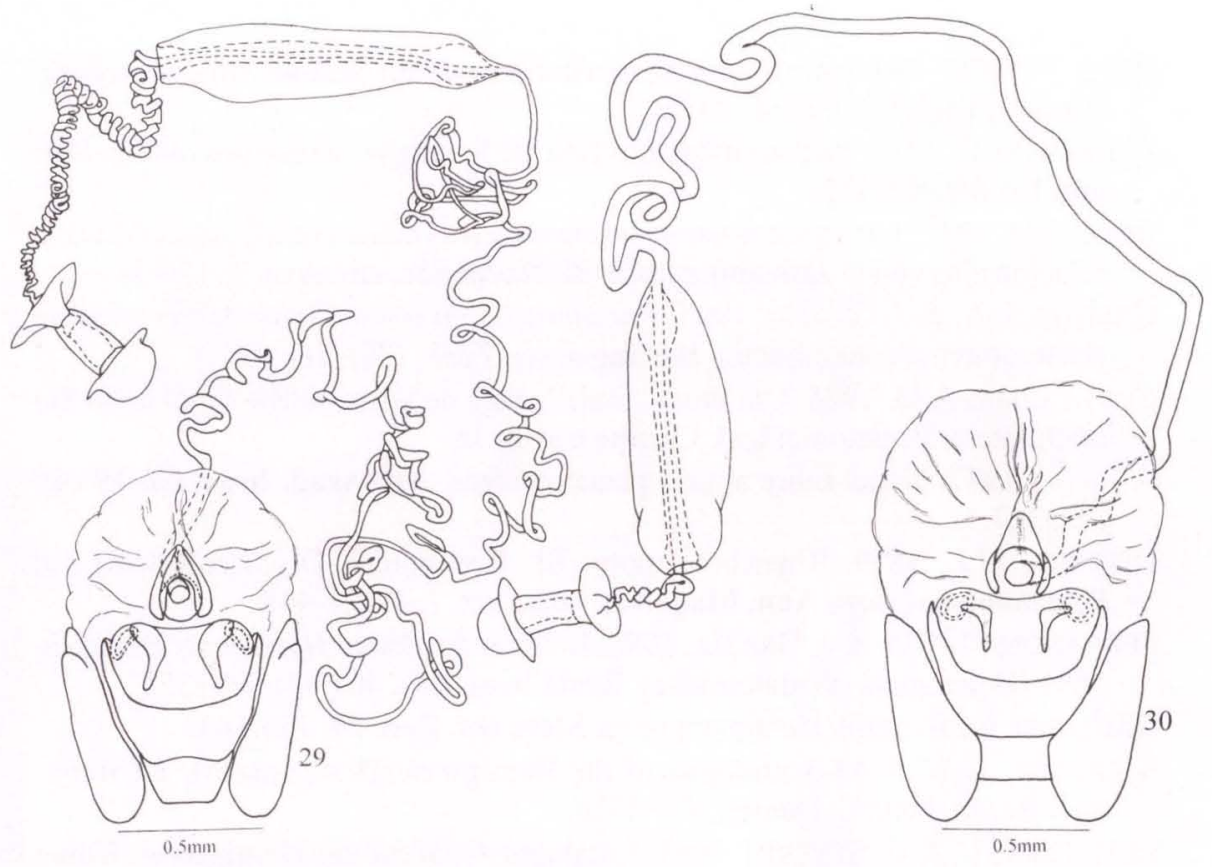

Figs 29-30. Laterotergites, gonocoxites and gonapophyses of ninth segmment, and ectodermical genital ducts, ventral view. (29) Tibraca exigua; (30) Tibraca similima. (aac) Anterior annular crest, (ch) chitinellipsen, (cs) capsula seminalis, (dur) ductus receptaculi, (g9) gonapophyses of ninth segment, (gc9) gonocoxites of ninth segment, (la9) laterotergites of ninth segment, (pac) posterior annular crest, (pco) pars communis, (pi) pars intermedialis, (st) secondary thickenings of gonapophyses 9 , (tvi) thickening of vaginal intima, (va) vesicular area, (x) tenth abdominal segment.

ACKNOWLEDGEMENTS. The authors are grateful to the curators of the collections for the loaning of the types studied in this paper, as follows: Dr. P. Lindskog (NHRS), R. Froeschner (USNM) and J. Margerison-Knight (BMNH).

\section{REFERENCES}

AMORIM, D.S. \& M.R.S. PIRES. 1996. Neotropical biogeography and a method for maximum biodiversity estimation, p.183-219. In: C.E.M. BICUDO \& N.A. MENEZES (Eds). Biodiversity in Brazil, a first approach. São Paulo, CNPq, $\mathrm{VI}+326 \mathrm{p}$.

BARBER, H.G. 1941. A new species of Tibraca, injurious to rice in Ecuador (Hemiptera-Heteroptera: Pentatomidae). Proc. ent. Soc. Wash. 43: 110.

BECKER, M. \& J. GRAZIA-VIEIRA. 1971. Contribuição ao conhecimento da superfamília Pentatomoidea na Venezuela (Heteroptera). Iheringia, sér. Zool., (40): 3-26.

Benvegnú, G.Q. 1968. "Paramecocephala" um novo gênero de Pentatomini do Brasil (Hemiptera, Pentatomidae, Pentatominae). Rev. Brasil. Biol. 28 (1): 87-96. 
BERG, C. 1879. Hemiptera Argentina enumeravit speciesque novas escripsit. Bonarie, Pauli E. Coni ed., 316p.

Bergroth, E. 1914. Pentatomidae noveaux de la Guyane Française. Annls Soc. ent. Fr. 83: 431-432.

BosQ, J.M. 1937. Lista preliminar de los hemipteros (heteropteros), especialmente relacionados con la agricultura nacional. Revta Soc. ent. Arg. 9: 11-134.

CAMPos, L.A. \& J. GraZIA. 1995. Paratibraca, um novo gênero de Pentatomini (Heteroptera, Pentatomidae). Iheringia, sér. Zool., (79): 163-171.

Costa Lima, A.M. 1935. Um novo "frade" praga de arroz no Rio Grande do Sul (Hemiptera: Pentatomoidea). Campo 6 (10): 16.

311-313.

Distant, W.L. 1899. Rhynchotal notes III. Heteroptera: Discocephalinae and Pentatominae (part). Ann. Mag. Nat. Hist., ser. 7, 4: 421-445.

FERNANDES, J.A.M. \& J. GRAZIA. 1996. Revisão do gênero Hypatropis Bergroth,

1891 (Heteroptera, Pentatomidae). Revta bras. Ent. 40 (3/4): 341-352.

HAGLund, E.J.C. 1868. Hemiptera nova. Stett. ent. Zeit. 29: 150-163.

Kirkaldy, G.W. 1909. Catalogue of the Hemiptera (Heteroptera). 1-Cimici-

dae. Berlin. Felix L. Dames, XL+392p.

Lethierry, L. \& G. Severin. 1893. Catalogue Général des Hemiptéres. Tome

I. Hétéroptères Pentatomidae. Bruxelles, Mus. R. Hist. Nat. Belgique, $\mathrm{X}+286 \mathrm{p}$.

MAYR, G.L. 1864. Diagnosen neuer Hemipteren. Verh. Zool.-bot. Ges. Wien. 14: 903-914.

PIRÁN, A.A. 1956. Hemipteros raros o poco conocidos y no mencionados para las faunas de Brasil, Uruguay, Argentina, Paraguay y Bolivia. Revta Soc. urug. Ent. 1 (1): 29-35.

RufFinelli, A. \& A.A. PIRÁN. 1959. Hemipteros heteropteros del Uruguay. Bolm Fac. Agron. Montevideo 51: 3-60.

Silva, A. 1945. Sobre a identidade de Tibraca limbativentris Stål, 1860 e Ogmocoris reinigeri Costa Lima, 1935. Ch. Quint. 72 (1945): 596.

STÅL, C. 1860. Bidrag till Rio de Janeiro - Traktens Hemipter-fauna. K. svenska VetenskAkad. Handl. 2 (7): 1-84.

1867. Bidrag till hemipterernas systematik. Öfvers. K. VetenskAkad. Förhandl. 24: 491-560.

. 1872. Enumeratio Hemipterorum II. K. svenska VetenskAkad. Handl. 10 (4): 1-159.

TRUJILLO, M.R. 1991. Chinche grande del arroz. Biologia y control. Corrientes, Estacion Experimental Agropecuaria, INTA, Argentina, 16p.

WALKER, F. 1868. Catalogue of the specimens of Hemiptera-Heteroptera in the collection of the British Museum. Part 3. London, British Museum, p. 419-599.

Recebido em 29.VIII. 1997; aceito em 26.XI.1998. 